\title{
Survey of Wholesale Production Nurseries Indicates Need for More Education on the Importance of Plant Species Diversity
}

\author{
Nicole R. Polakowski, Virginia I. Lohr, and Teresa Cerny-Koenig
}

\begin{abstract}
Recent pest outbreaks, such as emerald ash borer and Asian longhorned beetle, have renewed concerns about the lack of genetic and species diversity in landscapes across the United States. However, the level of understanding of these issues by people in the green industry is not known. A survey on the knowledge of plant species diversity issues was distributed to Washington, U.S., wholesale nurseries. Respondents indicated a general awareness of the issue, but they had insufficient understanding of why the lack of species diversity is a problem. Respondents who had learned about plant species diversity in educational settings beyond high school were more likely than others to understand the issues. These results indicate the need for increased, in-depth education on why plant species diversity among landscape plants is important.

Key Words. Biodiversity; Genetic Diversity; Nurseries; Overplanting.
\end{abstract}

In urban landscapes throughout the United States, the same plant genera, and even species, are often planted repeatedly, leading to low urban landscape plant diversity (Galvin 1999; Merritt 2008). In Toledo, Ohio, 57\% of all urban trees are in the same genus: maple (Acer) (Raupp et al. 2006). In the city of Seattle, Washington, $38 \%$ of all maples are from one species: red maple (Acer rubrum) (Seattle Department of Transportation 2011). Overplanting occurs not just at the species level, but even at the cultivar level. In Iowa, $60 \%$ of all red maples sold are of one cultivar: Red Sunset $^{\circledR}$ (Acer rubrum 'Franksred') (Iles and Vold 2003).

Homogeneous plantings are susceptible to increased pest and disease attacks. Across the U.S., insects and pathogens, such as Dutch elm disease (Ophiostoma spp.) and now the emerald ash borer (Agrilus planipennis), have caused epidemic rates of tree deaths (Santamour 1990; Ball et al. 2007). The emerald ash borer has destroyed millions of ash trees (Fraxinus spp.). Other examples of recent pest and disease outbreaks include the Asian longhorned beetle (Anoplophora glabripennis) and sudden oak death (Phytophthora ramorum) (Ball et al. 2007).

In landscapes, both the number of different species (biodiversity) and the diversity within a specific species (genetic diversity) are important (Lankau and Strauss 2007). Both increase a landscape's resiliency to stress and disease, and both are crucial to the health of urban ecosystems (Endress 1990). With a greater variety of species on a site, there is a greater likelihood that survivors will exist following a major environmental disturbance (Flemer 1981; Merritt 2008). In the nursery industry, a few cultivars that have superior qualities based on today's conditions are selected and clonally propagated, yielding plants of known qualities, but with little genetic diversity (Morton and Gruszka 2008). When these cultivars are overplanted, there is a greater risk that an onslaught of new pests or environmental challenges will damage them and decimate large portions of our green areas (Iles and Vold 2003).

To reduce the risks of too many trees of the same species in one area, city foresters and arborists are seeking a greater variety of species to increase urban landscape diversity (Ries 2009; Sydnor et al. 2010). State and local governments have begun passing environmental regulations, and cities are fortifying their landscape ordinances (Merritt 2008; Zhang et al. 2009). For example, the city of Wichita, Kansas, passed an ordinance that regulates landscape coverage and plant type in addition to location of newly planted vegetation (McDonnell 2005). Homeowners and businesses in Wichita who install new plantings are directed to plants from a diverse "preferred species" list to prevent overuse of a small number of species.

"Challenges caused by serious new pests and diseases" has been listed as a major trend that will influence the introduction of new crops in the nursery industry (Widrlechner 2007), yet the current level of awareness in the industry of issues related to these challenges is unknown. To shed light on this, wholesale nursery producers - one segment of the green industry responsible for the introduction of new plants and capable of creating demand for new products with integrated branding and marketing strategies (Drew et al. 2010) - were surveyed. They were asked questions on biodiversity and genetic diversity in landscapes and about how they have gained knowledge of the issues.

\section{METHODS}

\section{Survey}

An online survey with items related to landscape plant diversity, production at wholesale nurseries, and demographics was created. 
To develop items with phrasing familiar to respondents (Dillman 2000), interviews about plant species diversity with 13 nursery professionals in Oregon, U.S., were taped. This was important because of potential confusion in terminology. In the green industry, "diversity" is used for genetic or multi-cultural differences as well as for new colors of common plants. "Overplanting" can refer to over reliance on plants with limited genetic range or to crowding large quantities of plants in an area for immediate impact. Ten horticulture or landscape architecture faculty members in Washington, Idaho, and Oregon reviewed the survey for content validity, and it was given to five students to ensure that it was reliable and easy to understand. The Washington State University Human Subjects Institutional Review Board approved the research.

\section{Respondents}

A list of companies with nursery licenses was acquired from the Washington State Department of Agriculture in 2007. Companies that were exclusively retail, had gone out of business, were not involved with plant production, or did not answer the phone number listed were removed, yielding 130 active wholesale nurseries. A description of the anonymous survey was sent to the person responsible for plant inventory decisions at each nursery. Two months later, a follow-up e-mail was sent to encourage participation. Completed surveys were obtained from 42 people in the wholesale nursery industry in Washington state. This response rate of $32 \%$ falls within an expected range for businesses (Dillman 2000).

Most of the respondents were owners of the business contacted $(75 \%)$ and had worked in the industry for more than 15 years (69\%; range of 3 to 68 years). The nurseries ranged in size from 0.5 to 500 acres (mean of 28 acres, median of three acres) and produced a wide range of crops, including vegetable starts, bedding plants, native plants, flowering shrubs, and shade trees. When asked how much acreage was devoted to producing their primary crop, responses ranged from 0.02 to 500 acres (mean of 19 acres, median of one acre).

\section{Data Analyses}

Responses of "strongly disagree," "disagree," "slightly disagree," "slightly agree," "agree," and "strongly agree" on all diversity statements were scored from one to six, respectively, and used to calculate a mean attitude for each statement (Appendix). Responses on seven statements (four where agreement could indicate an understanding of diversity and three where agreement could indicate a lack of understanding) were combined to create a "Plant Species Diversity Score" (Appendix) by summing the scores for the statements after converting them so that a higher value was associated with fuller understanding of diversity. Analysis of Variance was used to compare the Plant Species Diversity Score to demographic items. A significance level of $10 \%$ was used, so that possible relationships were unlikely to be overlooked and because the consequences of error in interpretation were minor.

\section{RESULTS AND DISCUSSION}

\section{General Knowledge of Plant Species Diversity Issues}

Nearly all respondents $(85 \%)$ were in agreement that "increasing the number of different plant species used in an area is important for biodiversity" (Appendix). The mean attitude of 4.78 indicated that most respondents have an awareness of plant species diversity issues. Responses on other statements, however, indicated their level of understanding may not be very deep. Only $56 \%$ indicated agreement that "lack of plant diversity in a given region is an ecological problem." The mean of 3.83 suggested that most people only slightly agreed with this statement. These two statements are similar; however, there is more of a value judgment involved in answering the second statement, which used the word "problem." Many respondents apparently saw no "problem" with the wide usage of particular plants. Promotion of the wide usage of particular plants is common in the media. This can be readily seen in articles encouraging people to replant American elm (Ulmus americana) with the small number of clones that are resistant to Dutch elm disease (Duffy 2009). Instead of promoting the prudent use of these clones, such articles often inadvertently promote the recreation of the circumstances that led to the elm's original demise.

Only $45 \%$ of respondents agreed that "planting more than $10 \%$ of the same plant species in a region greatly increases the risk of insect or disease outbreaks" (Appendix). This was unexpected, because the general 10-20-30 rule (plant no more than $10 \%$ of any species, $20 \%$ of any genus, or $30 \%$ of any family) has been widely discussed (Santamour 1990; Galvin 1999; Frank et al. 2006; Sydnor et al. 2010). The lack of full understanding of the need for increased biodiversity is supported by the fact that only $40 \%$ agreed that "planting large numbers of a single plant species in a commercial or residential landscape increases the likelihood of severe insect or disease outbreak."

On statements where agreeing may indicate a lack of awareness of diversity (Appendix), agreement ranged from 59\% for "elm trees that have died from Dutch elm disease should be replaced with the new disease-resistant elms" to $83 \%$ for "the wholesale nursery industry is already addressing the species diversity issue, because they frequently introduce new plants for customers." While agreement may indicate a lack of understanding of diversity issues, the means, which ranged from 2.56 to 3.22 , suggest the respondents were neutral or only slightly agreed with the statements. Views that are not strongly held, such as these, can be easily changed with education (Schafer and Tait 1986).

\section{Role of the Nursery Industry on Plant Species Diversity Issues}

Agreement with the statement that "most wholesale nurseries currently offer an adequate range of plants for their customers to choose from" was very high (78\%) (Appendix). This attitude is not supported by the results of a study that found that only $3 \%$ to $5 \%$ of trees desired by urban foresters in Ohio were available from nursery growers in Ohio (Sydnor et al. 2010). Agreement that "the nursery industry could easily add more species to their inventories" was also high $(67 \%)$. This is important if the issues with lack of diversity are to be addressed. Only $24 \%$ agreed that "voluntarily increasing the number of different plant species in their inventories would allow nurseries to avoid regulatory interference from state or federal authorities."

\section{Nursery Characteristics and Plant Species Diver- sity Awareness}

Plant Species Diversity Scores ranged from 13 to 38, with a mean of 24 (possible range was 7 to 42 , with higher numbers indicat- 
Table 1. Plant Species Diversity Score and its relationship to characteristics of the nursery where the survey respondents worked, considerations in deciding to add plant species, cultivars, or varieties to inventories, and source of knowledge on species diversity issues or educational level for Washington, U.S., wholesale nursery industry respondent.

\begin{tabular}{|c|c|c|c|c|}
\hline Survey subject & Percent $^{2}$ & Diversity $^{y}$ & $\Delta^{\mathrm{x}}$ & $\mathrm{P}^{\mathrm{w}}$ \\
\hline \multicolumn{5}{|l|}{ Nursery characteristic } \\
\hline Area for single most produced species is $<1$ acre & 42 & 26.3 & +3.4 & 0.07 \\
\hline Total area for wholesale production is $<2$ acres & 28 & 26.0 & +2.4 & 0.24 \\
\hline Inventory of cultivars or varieties is $>100$ & 54 & 25.5 & +2.0 & 0.30 \\
\hline Plants shipped out of state is $<20 \%$ of production & 75 & 24.6 & +1.2 & 0.61 \\
\hline \multicolumn{5}{|l|}{ Plant inventory decision considerations ${ }^{v}$} \\
\hline Last year's sales and profitability & 36 & 24.7 & +0.6 & 0.76 \\
\hline Customer requests & 67 & 24.1 & -0.6 & 0.75 \\
\hline Ease of growth and maintenance & 50 & 23.6 & -1.5 & 0.44 \\
\hline Overall plant preferences & 64 & 23.5 & -2.3 & 0.25 \\
\hline Sales and marketing info & 42 & 22.3 & -3.4 & 0.08 \\
\hline Production costs & 33 & 22.1 & -3.3 & 0.10 \\
\hline \multicolumn{5}{|l|}{ Species diversity knowledge source ${ }^{v}$} \\
\hline Professional organizations & 42 & 25.6 & +2.2 & 0.26 \\
\hline Trade journals and articles & 69 & 24.8 & +1.7 & 0.40 \\
\hline Government programs (USDA, WSDA) & 36 & 22.5 & -2.8 & 0.17 \\
\hline Education beyond high school ${ }^{u}$ & 61 & 25.7 & +3.7 & 0.05 \\
\hline
\end{tabular}

${ }^{\mathrm{z}}$ Percent of respondents who selected the characteristic, consideration, or source.

${ }^{y}$ Scale from 7 to 42 , with higher values indicating a greater awareness of diversity.

${ }^{\mathrm{x}}$ Change $=$ Diversity for respondents who selected the characteristic - Diversity for those who selected a different characteristic.

" Significance of change in diversity, based on ANOVA.

${ }^{v}$ Respondent could check more than one.

${ }^{u}$ Response based on overall level of schooling not on learning about plant diversity.

ing greater understanding). Respondents who worked at nurseries where the major crop was produced on less than one acre of land had a significantly higher score (26.3) than those whose major crop used more land (22.9) (Table 1). Other nursery characteristics were not significantly related to the Plant Species Diversity Score.

\section{Plant Inventory Decisions and Plant Species Diversity Awareness}

Respondents' primary considerations when deciding to add new plants to their inventories were "customer requests" $(67 \%)$, "overall plant preferences" $(64 \%)$, and "ease of growth and maintenance" (50\%) (Table 1). Respondents who selected "environmental concern" (22\%) had the highest Plant Species Diversity Score (25.6). Respondents who selected "sales and marketing info" (42\%) or "production costs" $(33 \%)$ as primary considerations had significantly lower scores (22.3 and 22.1, respectively) than did respondents who did not report them as primary considerations (25.7 and 25.4, respectively).

\section{Source of Knowledge on Plant Species Diversity}

When respondents were asked where they had "learned about the issues with having many similar plant species in a landscape," the most common response was "trade journals and articles" (69\%) (Table 1). The Plant Species Diversity Scores for people who selected "school or college classes" (26.8) and "university outreach" (26.8) were significantly higher than scores for those who did not report them as sources $(23.0$ and 23.3, respectively). The Plant Species Diversity Score for people who reported their educational level as more than high school (25.7) was significantly higher than for those with education at lower levels (22.0). This shows that institutions of higher education can play a role in conveying the complexities related to the need for plant species diversity both to students, through formal classes, and to industry professionals, through outreach programs and submissions to trade journals.

\section{CONCLUSIONS}

These results indicate there is a general understanding that diversity among plant species used in landscapes is ecologically important, but there is less understanding of why this is so or how it relates to everyday landscape practices. Confusion on this topic, which is complex (Rowntree 1998), may come from a number of places. For example, if the message is understood simply as a need to maximize diversity, then plants that contribute to diversity but are not suited to the climate of a particular site might be used (Ball et al. 2007). The desire for symmetry, especially in street tree plantings, based on design and aesthetic considerations, has contributed to landscape plant uniformity (Flemer 1981; Santamour 1990). Terminology related to diversity can also be confusing; some now refer to the issue as a need to limit overuse, and not as a need to increase diversity (Ball et al. 2007). Confusion also arises with questions of how to apply broad-scale ecological information to individual landscapes (Endress 1990; Rowntree 1998).

Our landscapes have taken on a new ecological importance as the human population has expanded into more and more natural areas. Overproduction of a small number of species and cultivars continues (Iles and Vold 2003), and now can impact nearly all of the United States. It took de- 
cades for Dutch elm disease to spread in the United States (Duffy 2009), but recently daylily rust (Puccinia hemerocallidis) spread from coast-to-coast in one year (Bergeron 2008).

This study showed that education on the need for plant species diversity in the green industry is important. Regardless of the level of familiarity with the issues, the attitudes expressed in this study, generally, were not strongly held. Such attitudes are much easier to change than strongly held ones (Schafer and Tait 1986), and so it is likely that increased education on the issues would raise awareness. This could come through formal university classes that train the next generation of horticulturists and landscape architects, or in trade journals and articles, which were cited by nearly $70 \%$ of respondents in this survey as being a source of information on this subject.

\section{LITERATURE CITED}

Ball, J., S. Mason, A. Kiesz, D. McCormick, and C. Brown. 2007. Assessing the hazard of emerald ash borer and other exotic stressors to community forests. Arboriculture \& Urban Forestry 33(5):350-359.

Bergeron, S. 2008. Daylily rust information page. Accessed 08/03/2009. $<$ http://www.daylilyrust.org/>

Dillman, D.A. 2000. Mail and internet surveys: The tailored design method. 2nd Edition. John Wiley and Sons, New York, NY. 464 pp.

Drew, J., N. Anderson, and D. Andow. 2010. Conundrums of a complex vector for invasive species control: a detailed examination of the horticultural industry. Biological Invasions 12:2837-2851.

Duffy, M.P. 2009. Elm trees make a comeback: Plant this traditional American tree in your landscape. Accessed 07/30/2009. <http://trees. suite101.com/article.cfm/elm_trees_make_a_come_back>

Endress, A.G. 1990. The importance of diversity in selecting trees for urban areas. Journal of Arboriculture 16(6):143-147.

Flemer, W., III. 1981. Mixing species of shade trees for beauty and safety. Journal of Arboriculture 7(3):57-63.

Frank, S., G. Waters, R. Beer, and P. May. 2006. An analysis of the street tree population of greater Melbourne at the beginning of the 21st century. Arboriculture \& Urban Forestry 32(4):155-163.

Galvin, M.F. 1999. A methodology for assessing and managing biodiversity in street tree populations: A case study. Journal of Arboriculture 25(3):124-128.

Iles, J.K., and A.M. Vold. 2003. Landscape tree cultivar preferences in Iowa, U.S. Journal of Arboriculture 29(6):331-336.

Lankau, R.A., and S.Y. Strauss. 2007. Mutual feedbacks maintain both genetic and species diversity in a plant community. Science 317:1561-1563.

McDonnell, T. 2005. Landscape ordinance guidebook. City of Wichita, KS. Accessed 07/30/2009. <http://www.wichita.gov/NR/ rdonlyres/60A8DB07-4135-476C-94F9-45442B2C6D24/0/LndscpGuidebk62009.pdf>
Merritt, G. 2008. Denver's past tree vigilance turns into nightmare on maple streets. Denver Post. Accessed 07/30/2009. <http://www.denverpost.com/newsheadlines/ci_5510593>

Morton, C.M., and P. Gruszka. 2008. AFLP assessment of genetic variability in old $v s$. new London plane trees (Platanus $\times$ acerfolia). Journal of Horticultural Science \& Biotechnology 83(4):532-537.

Raupp, M.J., A.B. Cumming, and E.C. Raupp. 2006. Street tree diversity in eastern North America and its potential for tree loss to exotic borers. Arboriculture \& Urban Forestry 32(6):297-304.

Ries, P.D. 2009. The search for species diversity. Digger 53(9):49-50, $52-53$.

Rowntree, R.A. 1998. Urban forest ecology: Conceptual points of departure. Journal of Arboriculture 24(2):62-71.

Santamour, F.S., Jr. 1990. Trees for urban planting: Diversity, uniformity, and common sense. Proc. 7th Metro. Tree Improvement. Alliance Conf. p. 57-65.

Schafer, R.B., and J.L. Tait. 1986. A guide to understanding attitudes and attitude change. North Central Regional Extension Publication 138. Ames, IA.

Seattle Department of Transportation. 2011. Seattle tree inventory. Accessed 05/23/2011. <http://www.seattle.gov/transportation/treeinventory.htm>

Sydnor, T.D., S. Subburayalu, and M. Bumgardner. 2010. Contrasting Ohio nursery stock availability with community planting needs. Arboriculture \& Urban Forestry 36(1):47-54.

Widrlechner, M.P. 2007. Old and new trends influencing the introduction of new nursery crops. Accessed 10/03/2011. <http://www.hort. purdue.edu/newcrop/ncnu07/pdfs/widrlechner237-245.pdf>

Zhang, Y., B. Zheng, B. Allen, N. Letson, and J.L. Sibley. 2009. Tree ordinances as public policy and participation tools: Development in Alabama. Arboriculture \& Urban Forestry 35(3):165-171.

Nicole R. Polakowski

Graduate Student

Department of Horticulture and Landscape Architecture

Washington State University

Pullman, WA 99164-6414, U.S.

Virginia I. Lohr (corresponding author)

Professor

Department of Horticulture and Landscape Architecture

Washington State University,

Pullman, WA 99164-6414, U.S.

lohr@wsu.edu

Teresa Cerny-Koenig

Adjunct Professor

Department of Horticulture and Landscape Architecture

Washington State University,

Pullman, WA 99164-6414, U.S. 
Appendix. Washington, U.S., wholesale nursery industry level of agreement on individual atitude statements on plant species diversity issues and the role of the nursery industry.

\begin{tabular}{|c|c|c|}
\hline Survey attitude statements & Percent $^{2}$ & Agreement $^{\mathrm{y}}$ \\
\hline $\begin{array}{l}\text { Statements where agreeing may indicate awareness of species diversity issues }{ }^{x} \\
\text { "Increasing the number of different plant species used in an area is important for } \\
\text { biodiversity." }\end{array}$ & 85 & 4.78 \\
\hline "Lack of plant diversity in a given region is an ecological problem." & 56 & 3.83 \\
\hline $\begin{array}{l}\text { "Planting more than } 10 \% \text { of the same plant species in a region greatly increases the risk } \\
\text { of insect or disease outbreaks." }\end{array}$ & 45 & 3.26 \\
\hline $\begin{array}{l}\text { "Planting large numbers of a single plant species in a commercial or residential } \\
\text { landscape increases the likelihood of severe insect or disease outbreaks." }\end{array}$ & 40 & 3.33 \\
\hline $\begin{array}{l}\text { Statements where agreeing may indicate lack of awareness of species diversity issues } \\
\text { "The wholesale nursery industry is already addressing the species diversity issue, } \\
\text { because they frequently introduce new plants for their customers." }\end{array}$ & 83 & 3.20 \\
\hline $\begin{array}{l}\text { "Pest problems with mass plantings of a single species in a landscape can be } \\
\text { adequately controlled with appropriate pest management." }\end{array}$ & 73 & 3.22 \\
\hline $\begin{array}{l}\text { "Elm trees that have died from Dutch elm disease should be replaced with the new } \\
\text { disease-resistant elms." }\end{array}$ & 59 & 2.56 \\
\hline $\begin{array}{l}\text { Statements on the role of the nursery industry } \\
\text { "Most wholesale nurseries currently offer an adequate range of genetically different } \\
\text { plants for their customers to choose from." }\end{array}$ & 78 & 4.29 \\
\hline $\begin{array}{l}\text { "The wholesale nursery industry could easily add more plant species to their } \\
\text { inventories." }\end{array}$ & 67 & 3.90 \\
\hline $\begin{array}{l}\text { "Voluntarily increasing the number of different plant species in their inventories would } \\
\text { allow nurseries to avoid regulatory interference from state or federal authorities." }\end{array}$ & 24 & 2.64 \\
\hline
\end{tabular}

z Percent of respondents who selected "strongly agree," "agree," or "slightly agree."

y Mean based on a scale from one ("strongly disagree") to six ("strongly agree").

${ }^{x}$ Statements used to create the Plant Species Diversity Score (see Table 1). 
Résumé. De récentes épidémies d'insectes destructeurs, telles celles de l'agrile du frêne et du longicorne asiatique, ont renouvelé les inquiétudes à propos du manque en diversité génétique ainsi qu'en espèces dans les aménagements aux États-Unis. Cependant, le degré de connaissance de ces enjeux par les professionnels de l'industrie verte n'est pas connu. Un sondage sur le degré de compréhension des enjeux liés à la diversité en espèces végétales a été distribué dans les pépinières en gros de l'état du Washington aux États-Unis. Les répondants ont mentionné être généralement conscients de l'enjeu, mais ils avaient une compréhension insuffisante du pourquoi un manque de diversité en espèces est un problème. Les répondants à qui on avait enseigné sur le sujet de la diversité en espèces au-delà du niveau scolaire secondaire comprenaient mieux les enjeux que les autres. Ces résultats font ressortir le besoin pour une éducation accrue et plus approfondie sur pourquoi une diversité en espèces végétales dans les aménagements paysagers est importante.

Zusammenfassung. Die kürzlich aufgetretenen Massenaufkommen von Schädlingen wie Eschenbock und asiatischem Bockkäfer haben die Befürchtungen über die genetische Verarmung und zurückgehende Artenvielfalt in den Landschaften der Vereinigten Staaten neu ansteigen lassen. Dennoch ist der Kenntnisstand zur Artenvielfalt und verwandten Themen bei Leuten aus der grünen Industrie nicht bekannt. Daher wurde in den größeren Baumschulen in Washington eine Umfrage über die Artenkenntnis gestartet. Die Antworten zeigten ein großes Bewußtsein für dieses
Thema, aber die Teilnehmer hatten nur ungenügendes Verständnis dafür, warum eine Verarmung der genetischen Vielfalt ein Problem darstellt. Die Teilnehmer, die etwas über Artenvielfalt in Ausbildungssituationen oberhalb der Hochschule gelernt hatten, zeigten ein größeres Verständnis als die anderen Teilnehmer. Diese Ergebnisse zeigen einen großen Bedarf an tiefergehender Ausbildung darin, warum eine Artenvielfalt unter Landschaftspflanzen eine so große Bedeutung hat.

Resumen. Los recientes rebrotes de plagas, tales como el barrenador esmeralda del fresno y el escarabajo de antenas largas de Asia, han renovado las preocupaciones acerca de la falta de diversidad genética y de especies en los paisajes a través de los Estados Unidos. Sin embargo, el nivel de entendimiento de estos temas por la gente en la industria verde no es conocido. Se distribuyó en las ventas de vivero en Washington, U. S. una encuesta sobre el conocimiento de la diversidad de especies de plantas. Los encuestados indicaron una conciencia general sobre el tema, pero con insuficiente entendimiento de por qué la falta de diversidad de especies es un problema. Los encuestados que tuvieron aprendizaje sobre la diversidad de especies en eventos educativos, más allá de la universidad, fueron más susceptibles que otros a entender estos temas. Los resultados indican la necesidad de incremento, en profundidad de educación, sobre por qué la diversidad de especies de plantas es importante en paisajes de plantas. 